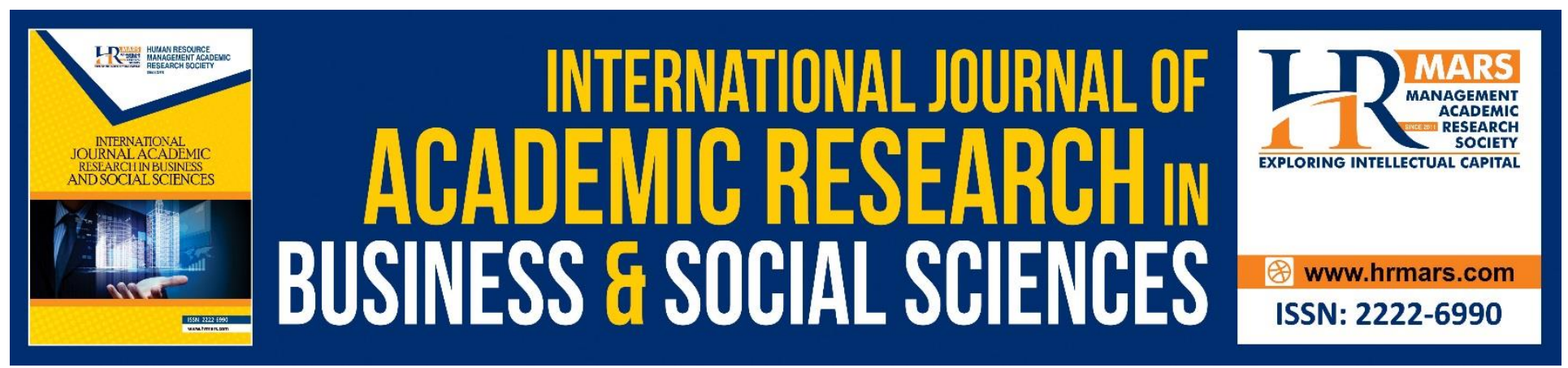

\title{
Strategy Implementation and Performance of HIV and AIDS Interventions Managed by Non-Governmental Organisations in Nyanza Region, Kenya
}

Leon Awiti, Richard Misigo Imbambi, Ng'ong'a E. Aketch, Moses Okumu

To Link this Article: http://dx.doi.org/10.6007/IJARBSS/v9-i3/5651 DOI: $10.6007 /$ IJARBSS/v9-i3/5651

Received: 26 Feb 2019, Revised: 11 March 2019, Accepted: 30 March 2019

Published Online: 14 April 2019

In-Text Citation: (Awiti, Imbambi, Aketch, \& Okumu, 2019)

To Cite this Article: Awiti, L., Imbambi, R. M., Aketch, N. E., \& Okumu, M. (2019). Strategy Implementation and Performance of HIV and AIDS Interventions Managed by Non-Governmental Organisations in Nyanza Region, Kenya. International Journal of Academic Research in Business and Social Sciences, 9(3), 219-238.

Copyright: (C) 2019 The Author(s)

Published by Human Resource Management Academic Research Society (www.hrmars.com)

This article is published under the Creative Commons Attribution (CC BY 4.0) license. Anyone may reproduce, distribute, translate and create derivative works of this article (for both commercial and non-commercial purposes), subject to full attribution to the original publication and authors. The full terms of this license may be seen at: http://creativecommons.org/licences/by/4.0/legalcode

Vol. 9, No. 3, 2019, Pg. 219 - 238

http://hrmars.com/index.php/pages/detail/IJARBSS

JOURNAL HOMEPAGE

Full Terms \& Conditions of access and use can be found at http://hrmars.com/index.php/pages/detail/publication-ethics 


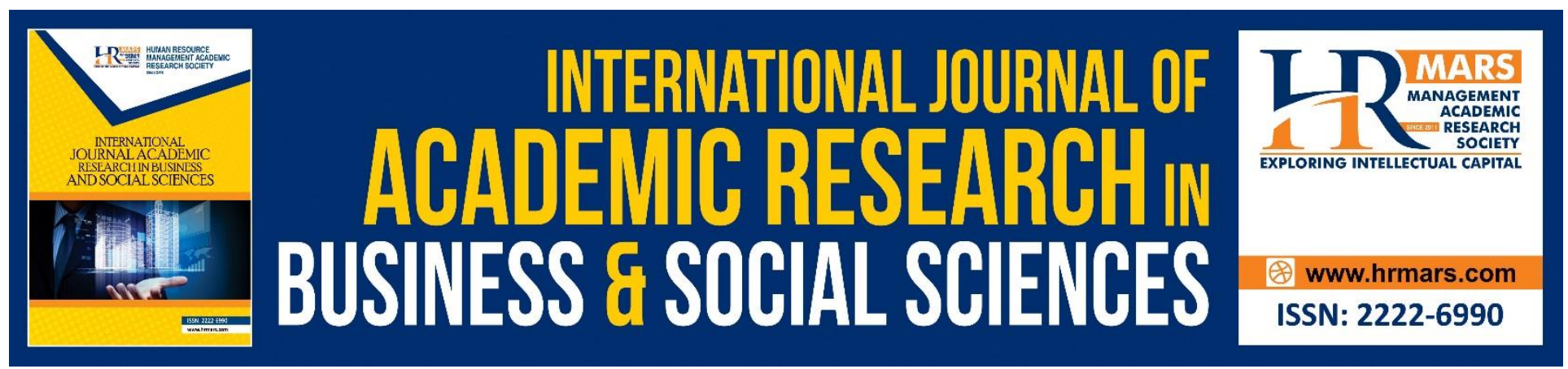

\title{
Strategy Implementation and Performance of HIV and AIDS Interventions Managed by Non-Governmental Organisations in Nyanza Region, Kenya
}

\author{
Leon Awiti, Ph.D. \\ Monitoring, Research, Evaluation and Learning Practitioner, Kenya \\ Email: awitileon@gmail.com
}

Richard Misigo Imbambi, Ph.D.

Email:rmimbambi@yahoo.com

Ng'ong'a E. Aketch, Ph.D.

Email: aketchngonga@yahoo.com

Moses Okumu

Email:moseso664@gmail.com

\begin{abstract}
This study sought to assess the influence of strategy implementation on performance of HIV and AIDS interventions managed by non-governmental organisations in Nyanza Region.This study used a positivist and interpretive paradigms adopting an ex post facto research survey design. Both quantitative and qualitative approaches. The target population for the study was 18 the departmental heads of program management, 18 monitoring and 18 evaluation and program implementation in NGOs registered by the NGO council as implementing HIV and AIDS interventions as a major focus and operating within Nyanza Region. The study also targeted the directors of the three governing bodies for HIV programming. The population was thus 60 respondents. Nonprobability purposive sampling was used to pick the respondents. The research used two instruments: questionnaires, Interviews schedules. Content validity was measured by using the Content Valid Index (CVI). The researchers used Cronbach's Alpha reliability to measure the internal consistency of the questionnaires, $r(11$ items $)=0.749$. Data analysis was done through descriptive statistics and inferential statistics such as Pearson correlation, hypothesis testing and multiple linear regression modeling. It was established that there was a significant strong positive relationship between strategy implementation and the performance of HIV interventions $r(50)=0.792, p-$
\end{abstract}


INTERNATIONAL JOURNAL OF ACADEMIC RESEARCH IN BUSINESS AND SOCIAL SCIENCES Vol. 9, No. 3, March, 2019, E-ISSN: 2222-6990 @ 2019 HRMARS

value $<0.001, \mathrm{CL}=95 \%$. The elements of strategy implementation that contributed most to performance of HIV and AIDS interventions were strategy adaptation $(\beta=8.829, p<0.001)$, strategy coordination $(\beta=7.707, p<0.001)$ and strategy communication $(\beta=6.007, p<0.001)$. Strategy translation made the least positive contribution to performance of HIV and AIDS interventions $(\beta=0.234, p=0.877)$. Strategy execution $(\beta=-4.328, p=0.047)$ was ineffective in enhancing performance of HIV and AIDS interventions. The NGOs managing HIV and AIDS interventions need to enhance strategy translation so as to make it clear what the short-term, as well as long-term goals are, this will enhance performance of interventions. There is also need to improve on strategy communication to ensure that every employee in the organisation understands the direction in which the organisation is intended to move. More emphasis need to be put on the execution of strategies since it was found to impact negatively on performance of HIV and AIDS interventions.

Keywords: Strategy implementation, Strategy translation, Strategy communication, Resource allocation, Coordination, Strategy execution and Strategy adaptation and Performance of HIV and AIDS

\section{Background of the Study}

Non-governmental organisations (NGOs) operating in several parts of Kenya, Nyanza included, are currently failing in the effective delivery of intervention programmes (Brass, 2012). Concerns are raised regarding the effective in their strategy implementation, which has been partly blamed for their poor performances. A major rising concern is the failure of the interventions directed towards prevention and management of HIV/AID since there are many new infections and more deaths at Nyanza region (KNASP, 2014).

Strategy translation is rewarding but it is easy to think the mission is accomplished when the plan has been crafted. No matter how great the thinking, strategy translation is useless until it is executed. Many senior managers are aware that developing strategy is just but the beginning of the process yet there are several researches that indicate that about $80 \%$ of strategic plans are poorly translated and communicated (Bechange, 2010). The key insight while doing strategy translation is that it is important to make sure that horizontal strategic leadership is involved, that different stakeholders of the intervention initiatives support each other in the delivery of strategy.

Communication of strategy is crucial because strategy needs to be properly understood by the stakeholders before it is implemented. Many senior leadership teams often fall into the trap of failing to effectively communicate the strategy (Brass, 2012). Even for successful NGOs that spend a great deal of time and effort in communicating the strategy the focus has been on communicating inputs (staff meetings, newsletters, and emails among others), instead of measuring how well the strategy has been understood. Therefore, instead of focusing on the inputs, the organisations should leverage on communicating outputs.

Resource allocation is a key management activity that facilitates strategy implementation. According to Bernal (2014), the real value of any resource-allocation programmes is based on the resulting achievement of organisational objectives. However, there are many factors that hinder effective resource allocation, such as putting much emphasis on short-term financial criteria, over-protection of resources, unclear strategy targets, organisational politics, a lack of adequate knowledge, and fear to take risk (Franklin, 2011). 
Coordination is crucial for the success of the overall strategic objectives, and this is achieved when all members are organised is such a manner that each of them contributes. All budgets and departmental plans have to be coordinated to make sure that they work together to attain organisational aims (Bebbington, Hickey, \& Mitlin, 2008). Coordination enables all participants and units to know what they are required to achieve and when, and in this way, tasks flow from one unit to another without obscurity. For instance, there are no idle time, clashes, role duplication, overstretched machinery or staff. The resources are also made available when and where they are required (Brass, 2012). In an efficiently run programme, while each unit has its own specific set of priorities, effective coordination enhances significant changes to be executed for the pursuit of an overall category of priorities.

Strategy execution is driven by performance culture, and this is realised only when hitting targets do not choke the strategic agility and innovation. According to Franklin (2011), a lack of understanding is a major impediment to the success of strategy execution, given that strategy execution is driven from the middle and not the top. While the senior leadership team may have accountability in developing and guiding the strategy, it is the middle management and team leaders who translate strategy for execution (Johnson, Scholes, \& Whittington, 2008). If insufficient effort is directed in making sure that the strategy is clearly understood, even less attention is given to supporting the strategy execution.

Strategy adaptation is important since organisations are complicated in one way or another. Complicated organisations never focus on doing one thing as they need to accomplish many tasks within a specific timeframe, and this makes strategy adaptation difficult (Bebbington, Hickey \& Mitlin, 2008). Stakeholders often fail to agree on a model of what the organisation is doing, what it should do, how it should do it or why. Therefore, a balanced scorecard is helpful when an organisation knows what it is trying to balance, and where it is going. Adaptation leads to long-term survival of organisations, but it is more than trying to simply the complicated organisation into a smaller niche. In Kenya, Nyanza region has been reported as having the highest HIV prevalence of $15.3 \%$ while the prevalence rate for the whole country is at 7.4\% (Kenya AIDS Response Progress Report, 2014). New infections are on the rise and more deaths continue to rock this part of the country. Despite, the NGOs operating in the region developing and implementing strategies to contain the pandemic, the performance of the HIV/AIDS interventions is still wanting.

\section{Statement of the Problem}

Non-governmental organisations (NGOs) operating in several parts of Kenya, Nyanza included, are currently failing in the effective delivery of intervention programmes (Brass, 2012). Concerns are raised regarding the effective in their strategy implementation, which has been partly blamed for their poor performances. A major rising concern is the failure of the interventions directed towards prevention and management of HIV/AID since there are many new infections and more deaths at Nyanza region (KNASP, 2014). In Kenya, Nyanza region has been reported as having the highest HIV prevalence of $15.3 \%$ while the prevalence rate for the whole country is at $7.4 \%$ (Kenya AIDS Response Progress Report, 2014). New infections are on the rise and more deaths continue to rock this part of the country. Despite, the NGOs operating in the region developing and implementing strategies to contain the pandemic, the performance of the HIV/AIDS interventions is still wanting. 
Johnson (2004) reports that 66 percent of corporate strategy is never implemented, this has led to project ineffectiveness and inefficiencies. While strategy implementation - frequently considered as the graveyard of strategy (Grundy, 1998) - was neglected, the main emphasis in strategy research has been on the formulation side of strategies (Grundy, 1998; Morris \& Jamieson, 2005). Strategy implementation among NGOs in Kenya remains a challenge resulting in well-formulated strategies that fail to be accomplished at the implementation stage. (Abok, Ogutu, Ragui, \& Waititu, 2013). Johansson and Nonaka (1996) and Ng'ethe (2005) observed that most strategic plans suffer from an 'execution gap'.

\section{Purpose of the Study}

1. To assess the influence of strategy implementation on performance of HIV and AIDS interventions managed by non-governmental organisations in Nyanza Region.

\section{Hypothesis of the Study}

1. $\mathrm{H}_{0}$ : There is no significant relationship between strategy implementation and performance of HIV and AIDS interventions managed by non-governmental organisations in Nyanza Region

\section{Empirical Literature Review Strategy Implementation}

The fourth step in strategic management is strategic implementation (David, 2013; Arasa \& K'Obonyo, 2012). Strategy implementation is an ongoing process where the strategy is translated into workable plans and metrics that can be controlled (Padersen, 2008).Strategy implementation is where the strategy gets communicated to the organisation, so that everyone involved knows the "what", "why" and "how" of the strategy (Bob de Wit \& Ron Ro, 2004). It is where the people, departments, budgets and resources involved are allocated and coordinated in a cooperating symbiosis (Padersen, 2008).

The first component of strategy implementation is strategy translation; the formulated strategy needs to be translated into the contemporary context of the organisation, so it becomes clear what the short-term, as well as long-term goals are. According to Bossidy and Ram (2004), there is no strategy that can deliver results unless it's converted into specific actions. The purpose of strategy translation, therefore, is to make the strategy understandable, workable and realistic. The practical outcome of the strategy translation process may be plans, goals, priorities, scorecards, milestones, key performance indicators, budgets, programs and teams. According to Padersen (2008), the purpose of strategy translation is to reduce uncertainty and incomprehensibility. According to Mankins and Steele (2006), what happens when the strategy is poorly translated is that: "Lower levels of the organisation don't know what they need to do when they need to do it, or what resources is be required to deliver the performance senior management expects. As expressed by Hrebiniak (2005); "When executing strategy, it is absolutely essential that the strategy is clear, focused and translated logically into short-term objectives or metrics.

The second component of strategy implementation is strategy communication. Communicating the strategy is about ensuring that every employee in the organisation knows and understands the direction in which the organisation is supposed to move, in-form of the business strategy. Kaplan and Norton's (2005) research reveals that as much as 95\% of the employees in an organisation typically 
are unaware or do not understand the company's strategy. No wonder why lots of companies find it difficult or virtually impossible to execute strategy. How are people supposed to know what to do, if they don't even know about the strategy in the first place? Hence, there are two main challenges about communication of the strategy; the first challenge is to make sure that the employees are aware of the strategy. That can be achieved through various internal communication venues, campaigns, briefings and meetings. The second challenge - is to ensure that people understand the strategy. That they know the why, what, how, when and who of the strategy and that they know exactly what individual role they have to perform in order to make the strategy happen.

The third component of strategy implementation is strategy coordination, suppose that the strategy has been translated into understandable and workable plans, priorities and milestones. Suppose that everyone in the organisation knows the strategy of the company. Suppose everything so far is in perfect order. Then what? Can an organisation now execute the strategy successfully? Probably not (Padersen,2008).In order to move to the next level, the organisation has to coordinate the strategy execution process; making sure that everyone knows what to do in the strategy execution process is therefore also a key factor in the endeavor. Otherwise, the strategy execution process may end up in confusion, misunderstanding, turmoil and eventually chaos. It is essential that key people in the strategy execution process are assigned both responsibility (to be the primary driver of a specific action or goal) and accountability (to be held liable for the implementation of said action or goal) for their individual part of the process (Hrebiniak, 2005), in order for them to reach the goals and milestones of the strategy. Everyone must know who is in charge - and accountable - for a particular action or goal. In coordinating the strategy execution process it is important to clarify which kind of interdependence exists between the involved people and departments.

The fourth component of strategy implementation is strategy adaptation. According to Mintzberg (1987), the strategy is; "a theory - a cognitive structure (and filter) to simplify and explain the world and thereby to facilitate action". Over time, however, the context inevitably evolves and changes; and so must also the assumptions, beliefs and estimates upon which the strategy is based. If they do not change, the strategy may not be successfully executed. According to Padersen (2008) for an organisation to adapt carefully to the constantly changing context they're in, the organisation has to be critical about their assumptions, beliefs and estimates. If the organisation fails to realize that the world has changed since they last reviewed their strategy, the organisation risks serious injury. Therefore, the organisation must frequently review their strategies as well as their assumptions, beliefs and estimates.

The fifth component of strategy implementation is resource allocation. Any strategy requires resources in order to be executed and implemented. Without proper resources, the strategy execution process freezes to a halt. Therefore, it is important for an organisation both to calculate the quantity and nature of resources the strategy execution process requires and allocate them accordingly. However, this doesn't seem to be obvious to every organisation. According to research conducted by Kaplan and Norton (2005), about 65\% of all companies never allocate sufficient resources to the strategy, thereby failing to create an appropriate connection between the strategy and the resources required to execute it. This obviously means that about two-thirds of the strategies made by companies never get past this threshold prerequisite of being attributed sufficient resources 
to be executed. This surely explains some of the reason why most strategies seemingly end their days in the drawer.

The sixth component of strategy implementation is strategy execution. According to Pedersen (2008), when all the preparation has been made in order to execute the strategy, only one element is missing to complete the strategy execution process: Pressing the button to implement the strategy. This is where all of the ideas, plans, resources and communication are converted to reality and the strategy can be felt and dealt with. This is where the reactions to the change come to life, both inside and outside of the organisation. Strategy execution is therefore about applying a strategy or change to a complex reality, of which no one can accurately predict the outcome.

It is therefore about dealing with both the known and the unknown factors that shapes, directs and decides the outcome of the strategy execution process. Consequently, it is only natural that a strategy ends up being implemented rather differently than it was intended to (Hrebiniak, 2005).

\section{Strategy Implementation and Performance of HIV and AIDS Interventions}

Dancy and Dutcher (2007) did a study on the HIV and AIDS information outreach: a community-based approach. The study adopted qualitative approaches. Interviews were conducted and final reports were analyzed, resulting in themes based on roles and responsibilities of participants and the impact of the projects in the communities. The study established that strategy translation and communication contributes to project performance. Results from the assessment suggest that access to HIV and AIDS information on the strategy led to improved communication between patients and their health care providers and encouraged better healthcare decision making. Feedback from reports and interviews included examples of the impact such as an increase in services provided to communities, national and global recognition of HIV and AIDS services, sustainability of projects and improved communication. The study concluded that community-based health dissemination of strategy information might empower the HIV and AIDS community to become more involved in healthcare and improve communication with providers.

Mulunga (2007) did a study on improving the effectiveness of strategic planning in local NGOs in Malawi. Employing qualitative methods, the study used the 'levels of complexity' and 'stages of organization development' models to analyze factors influencing the strategic planning and the roles and responsibilities played by the board, management, donors, consultants and communities respectively in five selected local NGOs. The study revealed that the level of implementation of the strategic plans was low (46\%). In comparison, the implementation was lower for organizational capacity building activities as compared to project activities. NGOs implementing HIV and AIDS interventions had higher levels of implementation as compared to their human rights counterparts. The major causes of the low implementation were the local NGOs' inadequate financial independence from donors to respond effectively and autonomously to the needs and priorities of their beneficiaries; and inadequate capacity for the boards, management, donors, consultants and communities to effectively go through strategic planning. The study recommended that there is the need for identifying alternative sources of funding while taking care not to be distracted from their core mandate and; Investing in the 'strategic capacity' of the board, management, donors, consultants and communities to effectively manage strategic management. 
Nyambura (2004) did a study on the communication patterns on HIV and AIDS Issues among adolescents in Nairobi Secondary schools. The main purpose of the study was to determine the managerial factors that influence the implementation of HIV and AIDS education program. The study used ex-post facto design. The subjects for this study were 79 HIV and AIDS teachers in Thika secondary schools. The study established that lack of funds/ facilities (resources) was a major obstacle to the management and implementation of the HIV and AIDS education program.

\section{Conceptual Framework}

The conceptual framework of the study is as shown in figure 1

Independent Variable

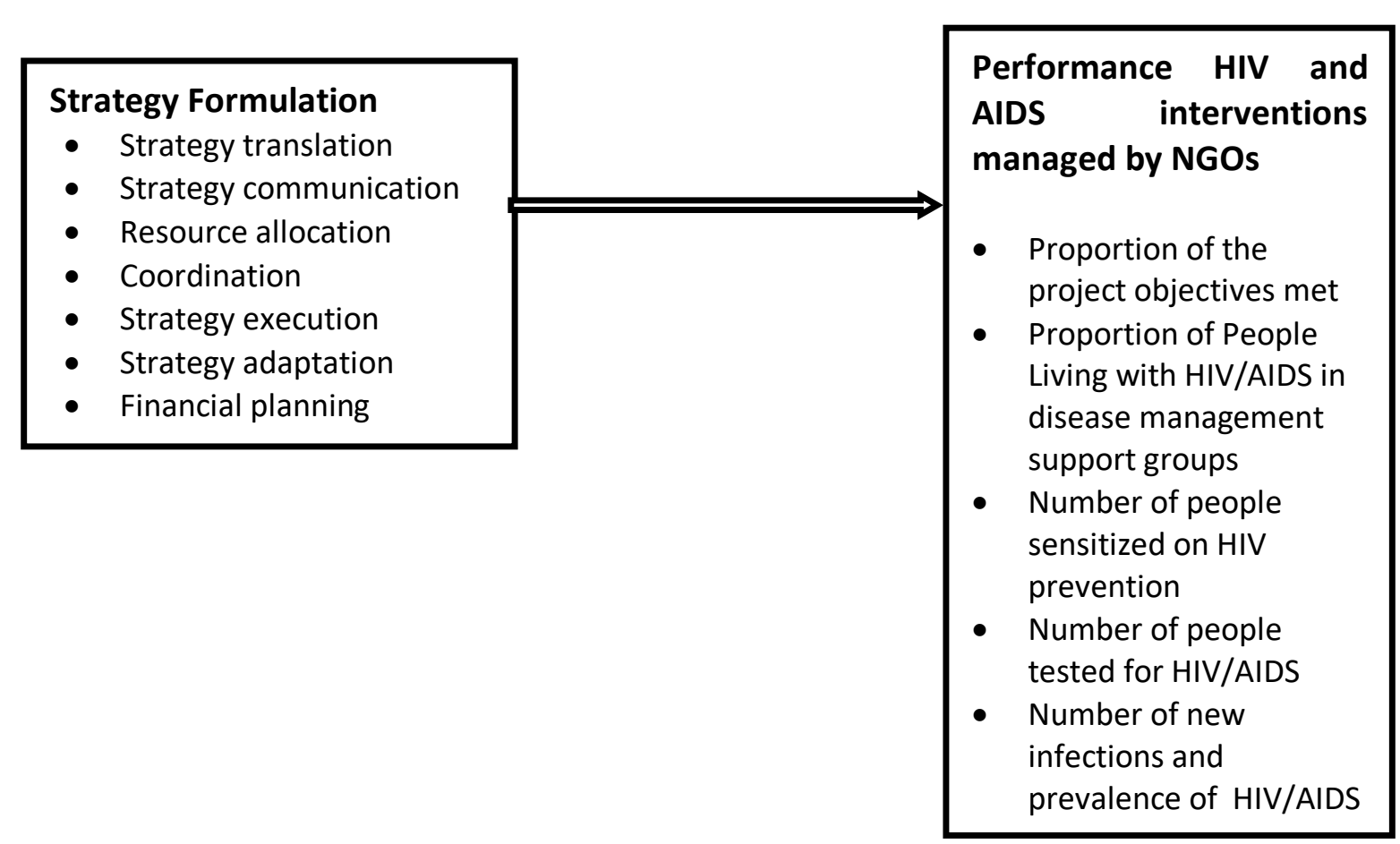

\section{Research Gaps}

Dancy and Dutcher (2007) did a study on HIV AND AIDS information outreach: a community- based approach strategy. The study only looked at two components of strategy implementation that is strategy translation and strategy communication. The influence of the other components of strategy implementation such as coordination, resource allocation, execution and strategy adaptation on project performance remains unknown.

Mulunga (2007) did a study on improving the effectiveness of strategic planning in local NGOs in Malawi. He established that the major causes of the low implementation of strategies were the local NGOs' inadequate financial independence from donors to respond effectively and autonomously to 
the needs and priorities of their beneficiaries; and inadequate capacity for the boards, management, donors, consultants and communities to effectively participate in the strategic management process. Still unknown is how the other aspects of strategic plans like strategy translation, strategy communication, strategy communication and strategy adaptation influence project performance. Muchira (2013) assessed the relationship between strategy implementation and performance in commercial banks in Kenya. The study found that strategy implementation influence organisation financial performance positively to a great extent resulting in increased organisation profitability, business turnover and volumes of sale. The study failed to interrogate the contribution of strategy implementation components like strategy translation, strategy communication, strategy communication and strategy adaptation, which are also critical.

\section{Methodology of the Study}

This study used a positivist and interpretive paradigms adopting an ex post facto research survey design. Ex-post facto research is one of the several well-established quantitative design methods to establish the direction and strength of relationships among variables under study. The study used both quantitative and qualitative approaches. The target population for the study was all the departmental heads of program management, monitoring and evaluation and program implementation in NGOs registered by the NGO council as implementing HIV and AIDS interventions as a major focus and operating within Nyanza Region. The NGOs meeting this criterion are 18 (NGO Coordination Board, 2013). The study also targeted the directors of the three governing bodies for HIV programming: Kenya AIDS NGO Consortium, National AIDS and AIDS and STDs Control program and Network of People National AIDS Control Council. The directors were targeted as key informants. According to NGO Coordination Board (2013), there were 18 NGOs having HIV and AIDS intervention as the main programming focus and operating in Nyanza Region, the sample size comprised the departmental heads of program/unit management, monitoring and evaluation and program implementation. The study picked the head of each department in the 18 NGOs giving a total of 54 respondents. The other category of respondents comprised the 6 Key Informants, they were drawn from three umbrella bodies coordinating Kenya AIDS NGO: National AIDS and AIDS and STDs Control program and Network of People National AIDS Control Council. The researcher used non-probability purposive sampling to pick the respondents. The research used two instruments: questionnaires, Interviews schedules. Content validity was measured by using the Content Valid Index (CVI). The researcher used Cronbach's Alpha reliability to measure the internal consistency of the questionnaires by checking how well the items are related to each other, $r(11$ items $)=0.749$. Data analysis was done through descriptive statistics and inferential statistics such Pearson Correlation, hypothesis testing, multiple linear regression modeling. 
INTERNATIONAL JOURNAL OF ACADEMIC RESEARCH IN BUSINESS AND SOCIAL SCIENCES

Vol. 9, No. 3, March, 2019, E-ISSN: 222 2-6990 @ 2019 HRMARS

Operationalization of Variables

Table 1: Operationalization of variables

\begin{tabular}{|c|c|c|c|c|c|}
\hline Objectives & Variable & $\begin{array}{l}\text { Indicators and } \\
\text { Dimensions }\end{array}$ & $\begin{array}{l}\text { Measuremen } \\
\text { t Scale }\end{array}$ & $\begin{array}{l}\text { Research } \\
\text { Approach }\end{array}$ & $\begin{array}{l}\text { Tools of } \\
\text { Analysis }\end{array}$ \\
\hline $\begin{array}{l}\text { To assess how } \\
\text { strategy } \\
\text { implementatio } \\
n \text { influences } \\
\text { performance } \\
\text { of HIV and } \\
\text { AIDS } \\
\text { interventions } \\
\text { managed by } \\
\text { non- } \\
\text { governmental } \\
\text { organisations } \\
\text { in Nyanza } \\
\text { Region }\end{array}$ & $\begin{array}{l}\text { IV } \\
\text { Strategy } \\
\text { implementatio } \\
n \\
\text { DV } \\
\text { Performance } \\
\text { of HIV and } \\
\text { AIDS } \\
\text { interventions } \\
\text { managed by } \\
\text { non- } \\
\text { governmental } \\
\text { organisations }\end{array}$ & $\begin{array}{l}\text { IV } \\
\text { - Strategy } \\
\text { translation, } \\
\text { - Strategy } \\
\text { communicatio } \\
\text { n, } \\
\text { - Resource } \\
\text { allocation, } \\
\text { - Strategy } \\
\text { execution, } \\
\text { - Coordination, } \\
\text { - Strategy } \\
\text { adaptation }\end{array}$ & $\begin{array}{l}\text { Nominal } \\
\text { Ordinal } \\
\text { Interval }\end{array}$ & $\begin{array}{l}\text { Quantitativ } \\
\text { e } \\
\text { Qualitative }\end{array}$ & $\begin{array}{l}\text { Descriptiv } \\
\text { e statistics } \\
\text { Linear } \\
\text { regression } \\
\text { ANOVA } \\
\text { Content } \\
\text { analysis }\end{array}$ \\
\hline
\end{tabular}


INTERNATIONAL JOURNAL OF ACADEMIC RESEARCH IN BUSINESS AND SOCIAL SCIENCES

Vol. 9, No. 3, March, 2019, E-ISSN: 222 2-6990 (C) 2019 HRMARS

\section{Study Findings}

\section{Biodata of the Respondents}

The biodata of the respondents was as shown in Table 2

Table2 : Biodata of the Respondents

\begin{tabular}{|c|c|c|c|}
\hline Variables & Categories & $\mathrm{F}$ & $\%$ \\
\hline \multirow[t]{4}{*}{ Programme focus of interventions } & HIV prevention & 18 & $36 \%$ \\
\hline & HIV Treatment & 3 & $6 \%$ \\
\hline & Both & 29 & $58 \%$ \\
\hline & Total & 50 & $100 \%$ \\
\hline \multirow{5}{*}{$\begin{array}{l}\text { Department of respondents in the } \\
\text { organization }\end{array}$} & Project/Unit manager & 15 & $30 \%$ \\
\hline & Implementing officer & 15 & $30 \%$ \\
\hline & M\&E officer & 14 & $28 \%$ \\
\hline & Field Coordinator & 6 & $12 \%$ \\
\hline & Total & 50 & $100 \%$ \\
\hline \multirow[t]{5}{*}{ Number of skilled employees } & Less than 10 & 20 & $40 \%$ \\
\hline & $11-20$ & 10 & $20 \%$ \\
\hline & $21-30$ & 6 & $12 \%$ \\
\hline & Over 30 & 14 & $28 \%$ \\
\hline & Total & 50 & $100 \%$ \\
\hline \multirow{4}{*}{$\begin{array}{l}\text { Onset of the current strategic planning } \\
\text { period }\end{array}$} & Less than a year ago & 22 & $44 \%$ \\
\hline & $1-3$ years ago & 9 & $18 \%$ \\
\hline & Over 3 years ago & 19 & $38 \%$ \\
\hline & Total & 50 & $100 \%$ \\
\hline \multirow{3}{*}{$\begin{array}{l}\text { Conclusion of the current strategic } \\
\text { period }\end{array}$} & Less than 5 years & 45 & $90 \%$ \\
\hline & 5 - 10 years & 5 & $10 \%$ \\
\hline & Total & 50 & $100 \%$ \\
\hline \multirow[t]{4}{*}{ Initiation of strategic planning process } & Following donor's request & 5 & $10 \%$ \\
\hline & Recognizing the need & 43 & $86 \%$ \\
\hline & Chronological requirements & 2 & $4 \%$ \\
\hline & Total & 50 & $100 \%$ \\
\hline \multirow{3}{*}{$\begin{array}{l}\text { Sequence of organizational structure } \\
\text { and strategic plan }\end{array}$} & Organizational structure & 37 & $74 \%$ \\
\hline & Strategic plan & 13 & $26 \%$ \\
\hline & Total & 50 & $100 \%$ \\
\hline \multirow{5}{*}{$\begin{array}{l}\text { Period of implementation of HIV and } \\
\text { AIDS interventions }\end{array}$} & Less than five years & 10 & $20 \%$ \\
\hline & $5-10$ years & 20 & $40 \%$ \\
\hline & $11-15$ years & 14 & $28 \%$ \\
\hline & Over 15 years & 6 & $12 \%$ \\
\hline & Total & 50 & $100 \%$ \\
\hline \multirow{3}{*}{$\begin{array}{l}\text { Annual budget for HIV and AIDS } \\
\text { interventions }\end{array}$} & Less than five Million & 3 & $6 \%$ \\
\hline & 5-10 Million & 11 & $22 \%$ \\
\hline & $11-15$ Million & 9 & $18 \%$ \\
\hline
\end{tabular}


INTERNATIONAL JOURNAL OF ACADEMIC RESEARCH IN BUSINESS AND SOCIAL SCIENCES

Vol. 9, No. 3, March, 2019, E-ISSN: 222 2-6990 @ 2019 HRMARS

$\begin{array}{lll}\text { Over } 15 \text { Million } & 27 & 54 \% \\ \text { Total } & 50 & 100 \%\end{array}$

\section{Strategy Implementation and Performance of HIV and AIDS Interventions}

In soliciting the views of the respondents on strategy implementation, the study focused on: Strategy translation, Strategy communication, Resource allocation, Coordination, Strategy execution and Strategy adaptation. The respondents were given statements to react to in 5-point Likert Scale: 1Strongly Disagree (SD), 2-Disagree (D), 3-Neutral (N), 4-Agree (A) and, 5-Strongly Agree (SA). The results were as shown in Table 3.

Table 3: Strategy Implementation and Performance of Interventions

\begin{tabular}{|c|c|c|c|c|c|c|c|}
\hline Statements & SD & D & $\mathbf{N}$ & A & SA & $\overline{\mathbf{x}}$ & SD \\
\hline $\begin{array}{l}\text { Our strategy has been well } \\
\text { translated by the management } \\
\text { to the stakeholders and they } \\
\text { understand what it's all about }\end{array}$ & $0(0 \%)$ & $0(0 \%)$ & $2(4 \%)$ & $20(40 \%)$ & $28(56 \%)$ & 4.52 & 0.580 \\
\hline $\begin{array}{l}\text { Our strategy has been widely } \\
\text { communicated to the } \\
\text { stakeholders and they know the } \\
\text { direction the org. is taking }\end{array}$ & $0(0 \%)$ & $2(4 \%)$ & $5(10 \%)$ & $26(52 \%)$ & $17(34 \%)$ & 4.16 & 0.766 \\
\hline $\begin{array}{l}\text { Our organisation has a strong } \\
\text { financial capacity to implement } \\
\text { the strategic options }\end{array}$ & $0(0 \%)$ & $0(0 \%)$ & $14(28 \%)$ & $11(22 \%)$ & $25(50 \%)$ & 4.22 & 0.864 \\
\hline $\begin{array}{l}\text { Our organisation allocate } \\
\text { adequate resources for all the } \\
\text { planned activities }\end{array}$ & $1(2 \%)$ & $0(0 \%)$ & $10(20 \%)$ & $21(42 \%)$ & $18(36 \%)$ & 4.10 & 0.863 \\
\hline $\begin{array}{l}\text { There is proper coordination of } \\
\text { resources during the execution } \\
\text { of planned activities }\end{array}$ & $0(0 \%)$ & $3(6 \%)$ & $0(0 \%)$ & $17(34 \%)$ & $60 \%$ & 4.48 & 0.789 \\
\hline $\begin{array}{l}\text { Our org. see to it that all the } \\
\text { planned activities in the detailed } \\
\text { implementation plans are } \\
\text { executed }\end{array}$ & $0(0 \%)$ & $0(0 \%)$ & $0(0 \%)$ & $19(38 \%)$ & $31(62 \%)$ & 4.62 & 0.490 \\
\hline $\begin{array}{l}\text { Our strategy implementation } \\
\text { allow for flexibility and } \\
\text { adaptability to dynamic } \\
\text { environments }\end{array}$ & $0(0 \%)$ & $0(0 \%)$ & $6(12 \%)$ & $17(34 \%)$ & $27(54 \%)$ & 4.42 & 0.702 \\
\hline $\begin{array}{l}\text { Our strategy implementation } \\
\text { involves active participation of } \\
\text { org. staff }\end{array}$ & $0(0 \%)$ & $0(0 \%)$ & $3(6 \%)$ & $17(34 \%)$ & $30(60 \%)$ & 4.66 & 0.848 \\
\hline Mean of means & - & - & - & - & - & 4.40 & - \\
\hline
\end{tabular}


The majority of the respondents at $48(96.0 \%)$, stated that their strategy had been well translated by the management to the stakeholders, the minority at $2(4.0 \%)$ stated that their strategy had not been well translated by the management to the stakeholders with none of the respondents being undecided. This meant that majority of the organisations had translated their strategy into operational implementation sub-objectives and a set of actionable steps. The organisations shared the understanding with Bossidy and Ram (2004) that the strategy needs to be converted into specific actions to enhance its delivery, this they noted would make the strategy understandable. Hrebiniak (2005) also noted that when executing strategy, it is absolutely essential that the strategy is clear, focused and translated logically into short-term objectives or metrics. There were indications that the management had commitment having the strategy implemented well, a study by Ahmed (2015) revealed that top management commitment has a positive and significant influence on strategy implementation; that the level of commitment of top-level managers in an organisation is very instrumental to the whole process of strategy implementation, $\beta=0.204, p$-value $=0.034$. The item mean (4.52)> mean of means (4.40), SD=0.580 this implied that strategy translation by the management to the stakeholders contributed to strategy implementation to a large extent.

Most of the respondents at $43(86.0 \%)$, stated that their strategy had been widely communicated to the stakeholders, $5(10.0 \%)$ undecided whether their strategy had been widely communicated or not to the stakeholders while the least at $2(4.0 \%)$ stated that their strategy had not been widely communicated to the stakeholders. The strategy was communicated both internally and externally in the organization. This would ease out the strategy execution process since the stakeholders will be aware the vision, mission, strategy priorities and key activities. The findings of the study diverged from those of Kaplan and Norton's (2005) that 95\% of the employees in an organisation were typically unaware or do not understand the company's strategy. The item mean (4.16) < mean of means (4.40), $\mathrm{SD}=0.766$ this implied that strategy communication to stakeholder was an aspect that had not contributed to strategy implementation to a small extent.

Most of the respondents at $36(72.0 \%)$, stated that their organisation had a strong financial capacity to implement the strategic options, the minority at $14(28.0 \%)$ undecided whether their organisation had a strong financial capacity to implement the strategic options or not. Most organisation had a strong financial capability, which was critical for the execution of the strategic plan, it meant that the organisations were in a position to roll out their strategies to achieve their goals. The item mean (4.22) < mean of means (4.40), SD=0.864, this meant that strong financial capacity to implement the strategic options contributed to strategy implementation to a small extent.

It was popular among 39 (78.0\%), respondents to state that their organization allocated adequate resources for all the planned activities, 10 (20.0\%) undecided whether their organization allocated adequate resources for all the planned activities or not, $1(2.0 \%)$ respondents stated that their organization did not allocate adequate resources for all the planned activities. This meant that most NGOs managing HIV and AIDS interventions had apportioned funds with respect to the financial plans, this would allow the execution of project activities to run smoothly. A study by Obiajolum and Ngoasong (2008) among SMEs established that integrated management and budgeting were critical for firm's competitiveness and performance. The findings of the study diverge from those of Kaplan and Norton (2005) that about $65 \%$ of all companies never allocate sufficient resources to the strategy, thereby failing to create an appropriate connection between the strategy and the resources required 
to execute. The item mean $(4.10)<$ mean of means $(4.40), S D=0.863$, this meant that allocating adequate resources for all the planned activities contributed to strategy implementation to a small extent.

A larger population of the respondent at $47(96.0 \%)$ stated that there was proper coordination of resources during the execution of planned activities, $3(6.0 \%)$ stated that there was no proper coordination of resources during the execution of planned activities, none of the respondents was undecided. The assertion by Hrebiniak (2005) were well understood and implemented by the NGOs, he affirmed that in order to move to the next level, the organisation has to coordinate the strategy execution process; making sure that everyone knows what to do in the strategy execution process is therefore also a key factor in the endeavor. The item mean (4.48)> mean of means (4.40), SD=0.789, the meant that proper coordination of resources during the execution of planned activities contributed to strategy implementation to a large extent.

All the respondents $(100.0 \%)$, stated that their organisation saw to it that all the planned activities which were in the detailed implementation plans were executed with none neither disagreeing nor undecided. With the proper coordination of the human and financial resources, the organisations were able to implement all the planned activities as outlined in the detailed implementation plans. The program targets were, therefore, likely to be met this would then put the organisations on the right path towards enhancing the performance of the HIV and AIDS interventions. The item mean (4.62) > mean of means (4.40), SD=0.490, this meant that seeing to it that all the planned activities in the detailed implementation plans are executed contributed strategy implementation to a large extent.

Most of the respondents at $44(88.0 \%)$, stated that their strategy implementation allowed for flexibility and adaptability to dynamic environments, the minority at $6(12.0 \%)$ were undecided whether their strategy implementation allowed for flexibility and adaptability to dynamic environments or not. A sizeable proportion of the organisations appreciated that community development comes with a lot of dynamics which require that there be a constant review of progress and coming up with appropriate adjustments to ensure that the implementation remains on course. The finding of this study mirrors the observation of Padersen (2008) that organisation must frequently review their strategies as well as their assumptions, beliefs and estimates to successfully execute its strategy. The item mean (4.42)> mean of means (4.40), SD=0.702, this implied that flexibility and adaptability to dynamic environments contributed to strategy implementation to a large extent.

The majority of the respondents at 47 (94.0\%), noted that their strategy implementation involved the active participation of organizational staff. On the other hand, a minority at $3(6.0 \%)$ stated that their strategy implementation did not involve the active participation of organizational staff. This meant the staffs are able to make better day-to-day decisions, they would also feel a stronger bond of responsibility for making decisions hence effective engagement with other stakeholders. According to a study by Kraus (2006) formalization of the strategic planning process and the involvement of staff resulted in growth and better performance outcomes for the organization. The item mean (4.66) > mean of means (4.40), SD=0.848, this implied that actively involving staff in the strategy implementation process contributed to strategy implementation to a large extent. 
The respondents tended to agree most that organisation saw to it that all the planned activities in the detailed implementation plans were executed ( $S D=0.490)$. The degree of difference in opinions was greatest among the respondents on whether the organizations had a strong financial capacity to implement the strategic options ( $S D=0.864)$. The mean of means was 4.40 , this implied that strategy implementation was done to a large extent among NGOs managing HIV and AIDS interventions in Nyanza Region.

\section{Mode of communication of strategic plan and performance of HIV and AIDS infections}

The respondents were asked to mention the modes of communication that they used to communicate the strategic plan to stakeholders; further analysis was done on the effectiveness of the modes of communication in enhancing performance of HIV and AIDS interventions, findings presented in Table 4

Table 4: Communication of Strategic Plan and Performance of Interventions

\begin{tabular}{ll} 
Modes of communication & Frequency \\
\hline Verbally only & $0(0.0 \%)$ \\
Print only & $21(42.0 \%)$ \\
Both print and herbal & $29(58.0 \%)$ \\
Total & $50(100 \%)$ \\
\hline
\end{tabular}

Communication of the strategic plan to the stakeholders was largely done through both print and verbal means as mentioned by 29 (58.0\%) of the respondents, 21 (42.0\%) said the communication was done by print only. No organisation used verbal communication only as a way of socializing stakeholders on the strategic plan. It was established that NGOs that used both verbal and print communication enhanced performance of HIV and AIDS interventions ( $\beta=2.445, p=0.487)$.

\section{Role of staff in strategy implementation and performance of HIV and AIDS interventions} The respondents were asked to state the role of organizational staff during strategy implementation. Staffs were involved in converting the strategy into specific actions this is to make the strategy understandable, workable and realistic. This involves the preparation of plans, goals, priorities, scorecards, milestones, key performance indicators and budgets. Staffs were also involved in strategy communication to ensure that fellow staffs and partners know and understand the direction in which the organisation is supposed to move. Staff also took part in coordinating the strategy execution process ensuring that people understand their role in the implementation process.

They also made sure that everyone understands the kind of interdependence that exists between the staff and departments. The staff also mentioned to participate in the day to day tracking of progress in the implementation of the strategy.

\section{Key Informant Interview findings}

The interviewees noted that strategy implementation has been done properly and to a large extent in accordance with the strategic options and operational plans. However, it was also noted that some of the strategic options and the operational plans were never referred during the strategy implementation process, some of the strategy documents were kept and only pulled out during 
strategy reviews. Strategy implementation has been effective in enhancing the performance of HIV and AIDS interventions managed by NGOs in Nyanza Region.

"Strategy implementation has not been handled well because some of the proposed strategies and activities end up not being executed, this leaves a gap and compromises efficiency and effectiveness of programming." Said the director at Kenya AIDS NGO Consortium.

The study findings mirror the descriptive analysis that shows that strategy implementation has been lagging behind strategy formulation; the mean of means for strategy formulation was $(\bar{x}=4.96)$ while that of strategy implementation $(\bar{x}=4.40)$. The correlation and regression analysis also showed that strategy implementation had a positive influence on the performance of HIV and AIDS interventions managed by NGOs in Nyanza Region.

\section{Correlation between strategy implementation and performance of HIV and AIDS interventions}

The study conducted a bi-variate correlation test using Pearson's coefficient to analyse the direction and magnitude of the relationship between strategy implementation and performance of HIV and AIDS intervention, the results were as shown in Table 5.

Table 5: Correlation for Strategy Implementation and Performance of Interventions

\begin{tabular}{|c|c|c|c|c|}
\hline 1 & Variables & $\begin{array}{l}\text { Statistic } \\
\text { Descriptor }\end{array}$ & $\begin{array}{l}\text { Strategy } \\
\text { Implementation }\end{array}$ & $\begin{array}{l}\text { Project } \\
\text { Performance } \\
0.792^{* *}\end{array}$ \\
\hline Pearson's $r$ & $\begin{array}{l}\text { Strategy } \\
\text { Implementation }\end{array}$ & $\begin{array}{l}\text { Correlation Coefficient } \\
\text { Sig. (2-tailed) } \\
\mathrm{N} \\
\text { Correlation Coefficient } \\
\text { Sig. (2-tailed) } \\
\mathrm{N}\end{array}$ & $\begin{array}{l}1.000 \\
. \\
50 \\
0.792^{* *} \\
.000 \\
50\end{array}$ & $\begin{array}{l}0.792^{* *} \\
.000 \\
50 \\
1.000 \\
. \\
50\end{array}$ \\
\hline
\end{tabular}

It was established that there was a significant strong positive relationship between strategy implementation and the performance of HIV interventions $r(50)=0.792$, $p$-value $<0.001, C L=95 \%$. This meant that the conduct of strategy implementation impacted the performance of HIV interventions managed by NGOs in Nyanza positively.

Hypothesis testing between strategy implementation and performance of HIV AND AIDS interventions

The study tested the null hypotheses $\left(\mathrm{H}_{0}\right)$ using F-statistic to ascertain the statistical insignificance of the relationship between strategy implementation and performance of HIV and AIDS interventions, the results were as shown in Table 6.

Table 6: Hypothesis for Strategy Implementation and Performance of Interventions

\begin{tabular}{llcccc}
\hline & $\begin{array}{l}\text { Sum } \\
\text { Squares }\end{array}$ & of df & Mean Square & F & Sig. \\
\hline Between Groups & 6274.246 & 10 & 627.425 & 26.797 & .000 \\
Within Groups & 913.134 & \multicolumn{2}{c}{3923.414} & & \\
Total & 7187.380 & \multicolumn{2}{c}{49} & & \\
\hline
\end{tabular}


The study tested the null hypothesis $\left(\mathrm{H}_{0}\right)$ that there is no significant relationship between strategy implementation and performance of HIV and AIDS interventions managed by non-governmental organisations in Nyanza Region. The $F$ distribution table gave a reading of critical value $=2.08$ and $F$ $(10,39)=26.796,2.08<26.796$, therefore we reject the null hypothesis, this meant that it is statistically very unlikely that the null hypothesis $\left(H_{1}\right)$ is true. We revert to the alternative hypothesis $\left(\mathrm{H}_{1}\right)$ that there is a significant relationship between strategy implementation and performance of HIV and AIDS interventions. The outcome of the hypothesis testing corroborates with those of the correlation that there is a significant relationship between strategy implementation and performance of HIV and AIDS interventions. The findings of the inferential analysis supported the resource-based theory by (1984) as well as the human resource-based theory postulated by Paauwe (1998) resource capabilities are critical for better performance of the projects and organizations at large.

\section{Strategy implementation elements and performance of HIV and AIDS interventions}

The study performed a linear regression analysis to establish the relationship between the elements of strategy implementation and the performance of HIV and AIDS interventions managed by nongovernmental organisations in Nyanza Region, the findings were as shown in Table 7

Table 7: Strategy Implementation Elements and Performance of Interventions

\begin{tabular}{lllllllll}
\hline Model & \multicolumn{2}{l}{$\begin{array}{l}\text { Unstandardized t } \\
\text { Coefficients }\end{array}$} & \multicolumn{2}{c}{ Sig. } & \multicolumn{2}{c}{$\mathbf{9 5 . 0 \%}$ Cl for B } & \multicolumn{2}{c}{$\begin{array}{c}\text { Collinearity } \\
\text { Statistics }\end{array}$} \\
& B & S.E. & & & LB & UB & Tol. & VIF \\
\hline (Constant) & 77.116 & 7.422 & 10.391 .000 & 62.149 & 92.083 & \\
Strategy translation & .234 & 1.505 & .155 & .877 & -2.800 & 3.268 & .506 & 1.975 \\
Strategy communication & 6.007 & 1.013 & 5.932 & .000 & 3.965 & 8.050 & .641 & 1.560 \\
Resource allocation & 1.731 & .876 & 1.977 & .054 & -.035 & 3.497 & .675 & 1.482 \\
Strategy coordination & 7.707 & 1.147 & 6.721 & .000 & 5.395 & 10.020 & .471 & 2.123 \\
Strategy execution & -4.328 & 2.113 & -2.048 & .047 & -8.590 & -.066 & .359 & 2.786 \\
Strategy adaptation & 8.829 & .969 & 9.115 & .000 & 6.876 & 10.783 & .832 & 1.201 \\
\hline
\end{tabular}

The elements of strategy implementation that contributed most to performance of HIV and AIDS interventions were strategy adaptation $(\beta=8.829, p<0.001)$, strategy coordination $(\beta=7.707, p<0.001)$ and strategy communication $(\beta=6.007, p<0.001)$. Strategy translation made the least positive contribution to performance of HIV and AIDS interventions $(\beta=0.234, p=0.877)$. Strategy execution $(\beta=-4.328, p=0.047)$ was ineffective in enhancing performance of HIV and AIDS interventions. 
Direct Effect Regression Model

Table 8: Direct Effect Regression Model

\begin{tabular}{|c|c|c|c|c|c|c|}
\hline \multirow[t]{2}{*}{ Model } & \multicolumn{2}{|c|}{$\begin{array}{l}\text { Unstandardize } \\
\text { d Coefficients }\end{array}$} & \multirow{2}{*}{$\begin{array}{l}\text { Standardiz } \\
\text { ed } \\
\text { Coefficient } \\
\text { S } \\
\text { Beta }\end{array}$} & \multirow{2}{*}{ Sig. } & \multicolumn{2}{|c|}{$\begin{array}{l}95.0 \% \text { Confidence Interval for } \\
\text { B }\end{array}$} \\
\hline & B & $\begin{array}{l}\text { Std. } \\
\text { Error }\end{array}$ & & & Lower Bound & Upper Bound \\
\hline (Constant) & $\begin{array}{l}65.80 \\
6\end{array}$ & 9.286 & & .000 & 47.135 & 84.478 \\
\hline $\begin{array}{l}\text { Strategy } \\
\text { Implementation }\end{array}$ & 2.804 & .264 & .838 & .000 & 2.274 & 3.334 \\
\hline
\end{tabular}

Dependent Variable: Performance of HIV and AIDS interventions

The findings showed that strategy implementation positively influenced the performance of HIV and AIDS interventions managed by non-governmental organizations in Nyanza region, strategy implementation $(\beta=2.804, p<0.000)$

$Y=\beta_{0}+\beta_{1} X_{1}+\varepsilon$

This is substituted as:

$\mathrm{Y}=65.806+2.804 \mathrm{X}_{1}+3.88$

Whereby: $Y=$ Performance of HIV and AIDS interventions

ßo $=$ Constant

$\mathrm{X}_{1}=$ Strategy implementation

\section{Conclusions}

Organisations managing HIV and AIDS interventions practiced strategy implementation to a large extent. However, there was little evidence that the strategy implementation process was effective. Communication of the strategic plan to the stakeholders was largely done through both print and verbal means as mentioned. Verbal communication of strategy to the stakeholders was very unpopular as none of the Organisations utilized it, it would add value to use it along other communication approaches.

There was a significant positive association between strategy implementation and performance of HIV and AIDS interventions managed by non-governmental organisations in Nyanza Region. Strategy adaptation, strategy coordination, strategy communication and strategy translation were effective while strategy execution was ineffective in enhancing the performance of HIV and AIDS interventions. It is inferred that there was a significant positive relationship between strategy implementation and the performance of HIV interventions.

\section{Recommendations}

The NGOs managing HIV and AIDS interventions in Nyanza region need to enhance the effectiveness of their strategy implementation processes for better developmental outcomes. The NGOs managing HIV and AIDS interventions need to enhance strategy translation so as to make it clear what the shortterm, as well as long-term goals are, this will enhance performance of interventions. There is also 
INTERNATIONAL JOURNAL OF ACADEMIC RESEARCH IN BUSINESS AND SOCIAL SCIENCES

Vol. 9, No. 3, March, 2019, E-ISSN: 222 2-6990 ¿ 2019 HRMARS

need to improve on strategy communication to ensure that every employee in the organisation understands the direction in which the organisation is intended to move. More emphasis need to be put on the execution of strategies since it was found to impact negatively on performance of HIV and AIDS interventions.

\section{References}

Bebbington, A., Hickey, S., \& Mitlin, D. (2008). Can NGOs make a difference?: the challenge of development alternatives. London: Zed books.

Bechange, S. (2010). Retracted: Determinants of project success among HIV/AIDS nongovernmental organizations (NGOs) in Rakai, Uganda. The International journal of health planning and management, 25 (3), 215-230.

Bernal, V. (2014). Theorizing NGOs: States, Feminisms, and Neoliberalism. Durham: Duke University Press.

Brass, J.N. (2012). Blurring Boundaries: The Integration of NGOs into Governance in Kenya. Governance, 25 (2), 209-235.

Franklin, P. (2011). Relationship Between Strategic Planning and Non-profit Organizational Performance. Ph.D. dissertation, Capella University, United States. ProQuest Dissertations and Theses: (Publication No.3440040).

Johnson, G. Scholes, K. and Whittington, R. (2008). Exploring corporate strategy: text and cases. London: Pearson Education.

Kenya AIDS Response Progress Report (2014). Progress towards Zero. Retrieved from http://www.unaids.org/sites/default/files/country/documents/KEN_narrative_report_2014. pdf

KNASP (2014). Draft KNASP Review Reporting Format, Inception Report: Strategic Review of the Kenya National HIV and AIDS Strategic Plan (KNASP) 2005/06 - 2009/10 and Development of a New KNASP 2009/10-2013/14

Abok, A., Waititu, A., Ogutu, O., \& Ragui, M. (2013). A Resource-dependency perspective on the implementation of strategic plans in Non-Governmental organisations in Kenya. Prime Journal of Social Science, 2(4), 296-302.

Ahmed, M. O. (2015). Factors Influencing Strategy Implementation in the Bakery Industry in Mombasa County. The International Journal of Business \& Management, 3(8),185-200

Arasa, R., \& K'Obonyo, P. (2012). The Relationship between strategic planning and firm performance. International Journal of Humanities and Social Science, 2(22), 201-213.

Bossidy, L., \& Ram, C. (2004). Execution: The discipline of getting things done. New York: Crown Publishers.

Dancy, C.N., \& Dutcher. G.A. (2007). Did a study on HIV and AIDS information outreach: a communitybased approach strategy. Journal of the Medical Library Association, 95(3), 330-336.

David, F.R. (2013). Strategic management: Concepts and cases (11 $1^{\text {th }}$ ed.). Harlow: Pearson Education Ltd.

Grundy, T. (1998). Strategy implementation and project management. International Journal of Project Management, 16(1), 43-50. 
INTERNATIONAL JOURNAL OF ACADEMIC RESEARCH IN BUSINESS AND SOCIAL SCIENCES

Vol. 9, No. 3, March, 2019, E-ISSN: 222 2-6990 ¿ 2019 HRMARS

Hrebiniak, L. (2005). Making strategy work - Leading effective execution and change. Wharton: Wharton School Publishing.

Johansson, J.K, \& Nonaka, I. (1996). Relentless: The Japanese way of marketing. New York: Harper Collins.

Kaplan, R., \& Norton, P. (2006). Alignment: Using the balanced scorecard to create corporative synergies. London: Harvard University Press.

Mankins, M., \& Steele, R. (2006). Turning Great Strategy into Great Performance. Harvard Business Review, 8(3), $406-430$.

Morris, P., \& Jamieson, A., (2005). Moving from corporate strategy to project strategy. Project Management Journal, 36(4), 5-18.

Muchira, N.W. (2013). Relationship between strategy implementation and performance in commercial banks in Kenya. Unpublished PhD thesis, Nairobi: University of Nairobi.

Mulunga, W. M. (2007). Improving the effectiveness of strategic planning in local NGOs In Malawi. Unpublished PhD thesis, Pretoria: University of South Africa.

Ng'ethe, A. (2005). Why Organisations Struggle with Executing their Strategies? Msafiri (Kenya Airways In-flight Magazine) 50, 7 - 10.

NGO Coordination Board, (2013). Monies utilized by the NGO sector in Kenya. 2nd HIV capacity building partner's summit, Johannesburg, South Africa. Retrieved From http://www.slideshare.net/RegionalAIDSTraining/sekoh-nyadiero-ngo-board-kenya\#

Nyambura, J. (2004). Communication patterns on HIV and AIDS Issues among adolescents in Nairobi Secondary schools. Unpublished PhD thesis, . Nairobi: University of Nairobi.

Paauwe, J. (1998). HRM and Performance: The Linkage between Resources and Institutional Context. Unique Approaches in order to Achieve Competitive Advantage. RIBES working paper. Rotterdam: Erasmus University.

Padersen, L. (2008). Cracking the code: Strategy execution. Copenhagen: Copenhagen Business School.

De Wit, B. and Meyer, R. (2004). Strategy: process, content, context - an international perspective. ( $3^{\text {rd }}$ ed.). London: Thomson.

Obiajulum, A. \& Ngoasong, L. N. (2008) Budgetary and management control process in manufacturing (Doctoral dissertation, Malardalen University, Sweden).

Kraus, S. (2006) Strategische planungund Erfolg junger Unternehmen Gabler, Wiesbaden. 